\title{
Geographical Influences on the Language Skill of Elementary School Students in Lae-Lae Island Makassar City
}

\author{
Yusri, Andi Reza Hidayat \\ Makassar State University \\ Email: yusriugm@gmail.com
}

\begin{abstract}
This article describes how geographic factor influences students' language skill which in this case is the mastery of vocabularies. This study is a quantitative research with sociolinguistic approach. The respondents of this study were elementary school students that live in Lae-Lae Island, Makassar City, and as for the comparison the researcher took other respondents from other elementary schools in urban areas. The researcher selected 30 students from each school. The techniques used in this study were a vocabulary mastery test, observations, and interviews. The data analysis technique is descriptive analysis and independent sample $t$ test. The result indicates that there are significant geographical factors on the students' vocabulary mastery. Elementary students in urban area have higher skill in mastering vocabularies than those in Lae-Lae Island. In addition, the geographical factors also influence the type of their vocabularies mastered by the students. The students from Lae-Lae Island are better in mastering marine vocabularies than those of urban areas.
\end{abstract}

Keywords: geographical factors, language skill, vocabulary mastery, elementary school students, lae-lae islands

\section{INTRODUCTION}

Children's language skill requires attention since the early age. One of the functions of the early development of children's language ability is to enable them to communicate with their social environment which will directly influence their intellectual ability. According to Hartanto (2011:387), language ability is one of the indicators in children cognitive development. Early detection of children's language skill development is crucial to the success in maximizing the brain plasticity in the compensation of developmental disorders.

Nelson (2006:146) and Tarigan (1998:239) reveal that the development of language ability is an indicator of overall development of children's cognitive skill associated with their success in school. One of the developments of children's language skill is obtained from the communities, in which they live. It means that the process of personality formation resulted from the contact with the surrounding community can give a special feature in the child's language behavior.

There have been a lot of studies concerning children language skill, for example the studies conducted by Hurlock (1978) and Widdowson (1983). Hurlock (1978:24) concluded that children language skill is affected by the factors of socialfamily, intelligence, health, encouragement and relationship with friends. Therefore, a good environment will support a good language skill development; on the contrary a bad environment will result in a bad development of language ability.

A similar study was conducted by Widdowson (1983). Widdowson (1983: 59) concluded that 
children language skill can be seen from the development of their language acquisition. Therefore, children are strongly influenced by the environment, and it is not due to deliberate learning process. The environment mentioned in this case is home environment, school environment, and the community.

In the contrary with Hurlock (1978) and Widdowson (1983), Taylor (2006:81) and Gunarsa (1995:84) focused more on examining how parents influence the development of their children language skill. Based on his study, Taylor (2006:81) concluded that the more often the parents respond to their children's invitation to communicate, introduce lots of concepts and things, the better the children's developments in language skill will be.

Several studies have described the influence of social environment, such as family, school, or community, to the children language skill. Therefore, this research can be said to have a different topic as the study examines how the geographic environment indirectly gives influence on the children's language skill. The term geographic environment used in this study is the environment in which a child lives, such as mountains, coastal areas, or other geographical conditions.

As has been described earlier, many factors influence the development of children's language skill. Hetherington and Parke (1999:34) stated that each child has a different level of the development of language skill; it started from birth to adult, from the very basic to the most complex one. The development of language skill will increase with age and the stimulus acquired by the child.

A child's language skill will continually evolve. A child will learn a lot from his environment, thus a child's language skill is formed by the environment condition. The child's environment mentioned here includes the family, community, and peer environments. Through the communication established within the surrounding people or even just to pay attention to the communication established by other people, a child's language skill will continually evolve. In addition, a child's language skill development is also enriched by the environment in which they live. Therefore, a child's environment gives a great influence on the child's language behavior (Yusuf, 2006:106).
Hurlock (1978: 24) explained that there are several factors that influence children language skill, including the child's intelligence, environmental and socioeconomic factors. A child that has had a higher intelligence from his or her birth would be quicker in showing superior language acquisition than those children whose intelligence is at a low level. While the environmental factors referred in this case is, as described earlier, the environment - whether it is the neighborhood or school - that affects children's language. Moreover, socioeconomic factors also arguably influence the child's language skill. This is because a person's socio-economic situation gives an impact on several matters related to the child's language skill.

This study is a quantitative research with sociolinguistic approach. Through this approach, the researcher was able to understand how the geographical aspects indirectly influence the skill of vocabulary mastery of elementary school students who live in Lae-Lae Island, Makassar. The respondents of the study were elementary school students who live and learn in Lae-Lae Island Makassar with the total of 30 students, and as a comparison the researcher also took respondents from elementary school with the same level. They live and attend school in urban areas with the total of 30 students. According to Suharyadi (2009: 201), 30 respondents or more can be classified as a large sample and the data collected have a great opportunity for a normal distribution.

The subjects in this study were students of the $5^{\text {th }}$ and $6^{\text {th }}$ grades. The sampling technique used in the study is purposive sampling. The researcher used several considerations such as the same level of education, the average age group, and the fair proportion between male and female students.

The data collection technique used in the study was vocabulary mastery testing in which the students were given 15 minutes to write down all vocabularies that they know as many as possible. Through the test, the researcher will be able to see the vocabulary mastery of the students. The researcher also conducted interviews and participative observations. 
The data analysis techniques used in this study were descriptive statistic and independent sample $t$ test. Descriptive statistic was used to acquire the average of vocabulary mastery of both Lae-Lae Island elementary students and the city students. While the independent sample $t$ test was used to see whether there was a significant difference between the vocabulary mastery between the students of Lae-Lae Island and the students of the urban areas.

\section{VOCABULARY MASTERY SKILL}

This part shows the comparison of the vocabulary mastery of elementary students in the coastal and urban area. In order to discover the students' skill in the vocabulary mastery, a 15 minute vocabulary test was given to the students. The test was used to find out the number of vocabularies the students were able to write within 15 minutes. Below is the result of the vocabulary test of the students of the coastal and city:

Table 1

Vocabulary Mastery Skill of Students in the City

\begin{tabular}{cccc}
\hline Subject & $\begin{array}{c}\text { The number } \\
\text { of vocabulary }\end{array}$ & Subject & $\begin{array}{c}\text { The number } \\
\text { of vocabulary }\end{array}$ \\
\hline 1 & 41 & 16 & 39 \\
\hline 2 & 43 & 17 & 39 \\
\hline 3 & 40 & 18 & 38 \\
\hline 4 & 43 & 19 & 40 \\
\hline 5 & 44 & 20 & 41 \\
\hline 6 & 42 & 21 & 41 \\
\hline 7 & 42 & 22 & 41 \\
\hline 8 & 41 & 23 & 37 \\
\hline 9 & 40 & 24 & 37 \\
\hline 10 & 39 & 25 & 39 \\
\hline 11 & 40 & 26 & 40 \\
\hline 12 & 41 & 27 & 40 \\
\hline 13 & 41 & 28 & 41 \\
\hline 14 & 38 & 29 & 36 \\
\hline 15 & 37 & 30 & 39 \\
\hline
\end{tabular}

Based on Table 1, we can see the average vocabulary mastery of students living in the city, which is 40 vocabularies. Further explanation can be seen from the data elaborated above which has been separated into several categories and frequencies of each categorization.

\section{Table 2}

Categorization of Vocabulary Mastery Skill of Students in the City

\begin{tabular}{cc}
\hline $\begin{array}{c}\text { The number of words/15 } \\
\text { Minutes }\end{array}$ & $\begin{array}{c}\text { Frequencies/the number } \\
\text { of students }\end{array}$ \\
\hline $20-25$ & 0 \\
$26-30$ & 0 \\
$31-35$ & 0 \\
$36-40$ & 17 \\
$41-45$ & 13 \\
\hline Average & $\mathbf{4 0}$
\end{tabular}

Based on the table above, we can see that there are 17 respondents in category 36-40, while the other 13 respondents are in category 41-45. Furthermore, we will see the data of coastal area students.

Table 3

Vocabulary Mastery Skill of Students in the Coastal Area

\begin{tabular}{|cccc}
\hline Subject & $\begin{array}{c}\text { The number } \\
\text { of words }\end{array}$ & Subject & $\begin{array}{c}\text { The number } \\
\text { of words }\end{array}$ \\
\hline 1 & 31 & 16 & 35 \\
\hline 2 & 32 & 17 & 29 \\
\hline 3 & 31 & 18 & 30 \\
\hline 4 & 35 & 19 & 30 \\
\hline 5 & 29 & 20 & 31 \\
\hline 6 & 30 & 21 & 26 \\
\hline 7 & 27 & 22 & 28 \\
\hline 8 & 31 & 23 & 30 \\
\hline 9 & 36 & 24 & 31 \\
\hline 10 & 29 & 25 & 31 \\
\hline 11 & 30 & 26 & 29 \\
\hline 12 & 31 & 27 & 33 \\
\hline 13 & 31 & 28 & 30 \\
\hline 14 & 28 & 29 & 28 \\
\hline 15 & 33 & 30 & 31 \\
\hline
\end{tabular}

Based on Table 3 above, we can see the vocabulary mastery of students who live and 
learn at school in the coastal area. From the table, it can be seen that the average rate of students' skill in mastering vocabulary within 15 minutes is 30.5. Further explanation can be seen from the data elaborated above which has been separated into several categories and frequencies of each categorization.

Table 4

Categorization of Vocabulary Mastery Skill of Students in the Coastal Area

\begin{tabular}{cc}
\hline $\begin{array}{c}\text { The number of words/15 } \\
\text { Minutes }\end{array}$ & $\begin{array}{c}\text { Frequencies/the number } \\
\text { of students }\end{array}$ \\
\hline $20-25$ & 0 \\
$26-30$ & 15 \\
$31-35$ & 14 \\
$36-40$ & 1 \\
$41-45$ & 0 \\
\hline
\end{tabular}

From the table above, we can see that there are 15 respondents on the category 26-30, while 14 respondents are on the category $31-35$ and there is only one person placed on the category 36-40. Based on the data, we can see clearly the comparison of vocabulary mastery between students who live in the coastal and urban area.

Further explanation for the comparison of students' vocabulary mastery can be seen from Table 5 below:

From Table 5 above, we can see that the average of vocabulary mastered by the first group or the group of coastal area students is 30.35 , while the average of vocabulary mastered by the second group or the students of the city is 40 . Based on the data collected, we can see that the rate of vocabulary mastery of students who live in the city is higher than that of students living in the coastal area; there is a different rate in the average of vocabulary mastery that is 9.47 .

To find out whether there is a significant difference on the average between the two groups, we can see it from the Sig values (2 tailed) or $p$ value (Tulus, 2006:82). If the $p$ value $<0.05$, it can be concluded that there is a significant difference in the average rate of vocabulary mastery between students of coastal and urban area. In contrast, if the $\mathrm{p}$ value $>0.05$, it can be concluded that there is no significance difference in the average rate of vocabulary mastery between the elementary school students in coastal area and the city. Further explanation is presented in the table below:

Table 5

\begin{tabular}{cccccrr}
\hline \multicolumn{6}{c}{ Group Statistics } \\
\hline The number of & Group & & N & Mean & Std. Deviation & Std. Error Mean \\
words & Dimension1 & 1 & 30 & 40.00 & 1.912 & .349 \\
& 2 & 30 & 30.53 & 2.270 & .414 \\
\hline
\end{tabular}

Table 6

Independent Samples Test

\begin{tabular}{|c|c|c|c|c|c|c|c|c|}
\hline & \multirow{2}{*}{$\mathrm{F}$} & \multicolumn{2}{|c|}{$\begin{array}{l}\text { Levene's Test } \\
\text { for Equality of } \\
\text { Variances }\end{array}$} & \multicolumn{5}{|c|}{ t-test for Equality of Means } \\
\hline & & Sig. & $\mathrm{T}$ & Df & $\begin{array}{c}\text { Sig. } \\
\text { (2-tailed) }\end{array}$ & $\begin{array}{c}\text { Mean } \\
\text { Difference }\end{array}$ & $\begin{array}{l}\text { Std. Error } \\
\text { Difference }\end{array}$ & \\
\hline \multirow{2}{*}{$\begin{array}{l}\text { The } \\
\text { number } \\
\text { of words }\end{array}$} & $\begin{array}{c}\text { Equal variances } \\
\text { assumed }\end{array}$ & .323 & .572 & 17.470 & 58 & .000 & 9.467 & .542 \\
\hline & $\begin{array}{c}\text { Equal variances } \\
\text { not assumed }\end{array}$ & & & 17.470 & 56.368 & .000 & 9.467 & .542 \\
\hline
\end{tabular}


To find out whether there is a significant difference between the two groups, we can see from the Sig values (2 tailed) or $p$ value.

If sig $>\alpha(\cdot, 05)$, then $\mathrm{H}_{0}$ is rejected and $\mathrm{H}_{1}$ is accepted.

If sig $<\alpha(\cdot, 05)$, then $\mathrm{H}_{\mathrm{o}}$ is accepted and $\mathrm{H}_{1}$ is rejected.

Notes:

$\mathrm{H}_{0} \quad$ : There is a significant difference in the vocabulary mastery skill between the elementary students in Lae-Lae Island and city area.

$\mathrm{H}_{1} \quad$ : There is no significant difference in the vocabulary mastery skill between the elementary students in Lae-Lae Island and city area.

The sig value is 0,572 . Since to the sig value $>$ 0.05 , therefore, there is no different variants on the data of the two groups compared, which means that the data is homogeneous. Next, we look into the sig value on the equal variances assumed part that is 0.0000. Because the Sig value (2 tailed) is smaller than the probability value of 0.05 , therefore, the $\mathrm{H}_{\mathrm{o}}$ is accepted while $\mathrm{H}_{1}$ is rejected. Therefore, it can be concluded that there is a significance difference in the average rate of vocabulary mastery between the students living in coastal and city area. Therefore, it can be concluded that the skill of vocabulary mastery of the students living in the city area is higher than that of the hose students living in LaeLae Island, Makassar.

Based on the observations and interviews, it can be concluded that the differences in the vocabulary mastery occurred because of the difference of education quality received by the students; it was caused by the imperfection of education received by the students. The imperfection occurred due to the difference of geographical factors of the areas in which the two groups of students lived. Therefore, it can be concluded that geographical factors indirectly influence the vocabulary mastery.

\section{THE TYPE OF VOCABULARY MASTERY}

In the previous section, we discovered the comparison of vocabulary mastery between the students of coastal area and the city. Based on the section, it can be concluded that students who live in city area have a higher skill in vocabulary mastery than those living in the coastal area. The geographical factor mentioned in this study is the condition of the geographical environment which influences the occurrence of differences in the vocabulary mastery between the two groups.

It is clarified with the data obtained in this study. Based on the collected data, it can be seen that there is a difference in the type of vocabulary mastery between students who live in coastal area and those living in the city area. Students who live in the coastal area tended to write down vocabularies related to maritime as shown below:

Table 7

The Type of Vocabulary of students in Coastal Area

\begin{tabular}{lc}
\hline \multicolumn{1}{c}{ The Type of Words } & Frequencies \\
\hline Biseang (boat) & 23 \\
Tude (Shell) & 19 \\
Pekang (Inducement) & 21 \\
Juku (Fish) & 19 \\
Parengge (Fisherman) & 16 \\
Tamparang (Sea) & 15 \\
Sango-Sango (Seaweed) & 21 \\
\hline
\end{tabular}

The types of vocabulary mastery above are not found in the data collected from the group of students who live in city area. Most of the students living in city area tend to write down vocabularies related to technology and stationery such as:

Table 8

The Type of Vocabulary of students in the City

\begin{tabular}{cc}
\hline The Type of Words & Frequencies \\
\hline HP (hand phone) & 29 \\
Televisi (Television) & 26 \\
Motor (Motor cycle) & 23 \\
Mobil (Car) & 19 \\
Buku (Book) & 22 \\
Pulpen (Pen) & 18 \\
\hline
\end{tabular}

Based on the data presented, we can conclude that the environment that becomes the concern in this study is that the geographical factor influencex the type of vocabulary mastery within the community. Students from coastal area tend to master vocabularies related to maritime, different from the students who live in the city area. This is caused by the students' daily activities that relate 
to the maritime/marine conditions such as ocean, fishes, fisherman, etc.

The result of this study is in line with Sumarsono (2013:61) who asserted that the physical environment of a community can be reflected from their language; it means that environment can influence a community's language. One of them is the lexicon or the vocabulary as shown in this study, and it is influenced by geographical factors.

Moreover, the study shows that environment influences not only the language in its lexicon, but also the children's vocabulary mastery. Based on the research, it can be seen that students living in coastal area have lower vocabulary mastery than the students living in the city. This is caused by the fact that students in coastal area rarely see or experience things that are seen and experienced by the students living in the area.

The previously mentioned arguments on the factors influence children's' language skill, such as Widdowson (1983), Simkin (2006) and Yusuf (2006) argue that one of the factors influencing a child's language skill is external factor. The external factor mentioned here is a social environment where the child lives, such as family, school, and society environment. Based on the result of the study, we discovered that environment is able to influence children's language skill in vocabulary mastery, not only through the family, school, or society environment, but also the geographical situation where they live.

\section{CONCLUSION}

Based on the result of the study explained earlier, it can be concluded that the occurrence of the difference in vocabulary mastery is caused by the imperfection of education received by the students. The imperfection occurred due to the difference in geographical factors in which the two groups of students live. Based on the result, we could see that the vocabulary mastery of the students who live in urban city is higher than those living in the coastal area. This is caused by the quality of education received by the students who live in the city area which is higher than the education received by students living in the coastal area. In addition, the geographical factors concerned in this study do not influence only the skill of the students' vocabulary mastery, but also influence the type of vocabularies mastered by the students. The students who live in coastal area have a higher mastery in marine-related, different from the students living in the city.

\section{ACKNOWLEDGMENTS}

I hereby express my gratitude to Lembaga Pengelola Dana Pendidikan (LPDP) Indonesia for the fund that was given to me to conduct this research. I also express my gratitude to all lecturers of Post Graduate Linguistics Program of Universitas Gadjah Mada for their guidance during the process of conducting the research. Last but not least, I also express my gratitude to the Student Research Centre (LPM) of Universitas Makassar for their assistance and contribution to this research.

\section{REFERENCES}

Gunarsa, Singgih D. (2003).Developmental Psychology. Jakarta: BPK Gunung Mulia.

Hartanto, Fitri. Selina, hendriani dan Fitra, Zuhriah Saldi. (2011). The Influence of Language Development towards Cognitive Development of children aged 1-3 year. Journal of Sari Pediatri Volume 12 No. 6, April 2011.

Hetherington dan Parke. (1999). Child Psychology. New York: McGraw Hill.

Hurlock, Elizabert B. (1978). Child Development.Sixth Edition. New York: Mc. Graw Hill. Inc

Nelson HD, Nygren MA, Walker M, Panoscha R. (2006). Screening for speech and Language delay in preschool children: systemic evidence review of the US preventive service task force. Pediatrics 2006;117:293-317.

Simkin Z, Conti G. (2006). Evidence of reading difficulty in subgroups of children with specific language impairment. Child language teaching and therapy 2006;22;315-31.

Suharyadi, dan Purwanto.(2009). Statistic:For Economic and Finance. Modern. Jakarta : Salemba Empat.

Sumarsono.(2013). Sociolinguistic. Pustaka Pelajar: Yogyakarta

Tarigan.(1988). Language Acquisition Teaching, Bandung: Angkasa.

Taylor, E. S. Peplau, L. A., dan Sears, D. O. (2006). Social Psychology.12th. Ed. New Jersey: Prentice - Hall. 
Tulus Winarsunu. (2006). Statistic in Psychology and Education Research. UMM Press: Malang.

Widdowson, H. G. (1983). Teaching Language as Communication. Oxford: Oxford University Press.
Yusuf, Syamsu. (2006).Development Psychology of Children and Adults. Bandung; Remadja Rosdakarya. 